\title{
4.0 IR, Oversize Economy and the Extinction of Mammoth Companies
}

\author{
Silvio M. Brondoni*
}

\begin{abstract}
The $4^{\text {th }}$ Industrial Revolution (4.0 IR), fundamentally disrupts the technologies characterizing the first three industrial revolutions. In the nowadays global management phase (competitive globalisation), the business model based on excess supply (i.e., over-supply model, in which competitors face volatile production and progressively falling prices) is now inadequate for aggressive global corporate policies.

Producing more and wasting less require today a new global business model based on the progressive disappearance of marginal global companies (oversize economy, characterized by lower production and sales costs, and by large company size).

Standardized production has now fallen into a crisis that drives companies towards 4.0 technologies i.e., in the pursuit of new conditions of efficiency that are more open to innovation, towards productive flexibility, and even towards competitive imitation.
\end{abstract}

Keywords: 4.0 IR; Oversize Economy; Oversize Management; General Motors; Pontiac; Saturn; Oldsmobile; Polaroid; Compaq; Pan Am; Blockbuster; Kodak; Mammoth Companies; Global Competition

\section{Competitive Globalisation and the $4^{\text {th }}$ Industrial Revolution}

The $4^{\text {th }}$ Industrial Revolution (4.0 IR), developed by the largest corporations to establish more competitive scenarios, is the most recent on a global level. The $4^{\text {th }}$ Industrial Revolution fundamentally disrupts the technologies characterizing the first three industrial revolutions: the first based on the mechanization of industrial plants and centred on the textile sector; the second linked to the assembly line and integrated mass production systems; the third associated with the diffusion of information technologies in the digital age (Brondoni \& Zaninotto, 2018).

Globalisation is essentially the geographic extension of competitive markets, a process dependent on the removal of barriers, and overcoming distance through technology (Sigurdson, 1990). This trend has accelerated since the 1980s, as technological advances (the Internet and telecommunication infrastructures) have facilitated travel, communication, and doing business (Brondoni, 2014).

Since 2010, globalisation has imposed a new view of the competitive environment in which competitors are not always direct rivals. In megaorganisations, success is determined by the capacity to manage accumulated knowledge (inside-out

* Full Professor of Market-Driven Management, Niccolò Cusano University (silvio.brondoni@ unicusano.it) 
knowledge resources) and the sum of knowledge that can also be acquired externally through network relations (outside-in knowledge resources) (Brondoni, 2011).

The nowadays globalisation phase (competitive globalisation) is characterized by an increasing number of over-supplied markets, as well as a key-role of dimensional growth. The last one represents a fundamental driver for the firm's development, by determining its success or decline (Brondoni, 2008).

As a result of alliances and agreements, certain firms can become competitors in the sense that together they contribute to the common objective of generating greater profits, with megaorganisations that have the potential to change the long term competitive structure of sectors (oversize economy) (Brondoni, 2019).

In oversize economy, global companies move to adopt closed innovation policies, operating in sectors that became protected from competition. With global closed innovation policies, a certain number of megaorganisations concentrate their expertise in governing market power through innovation processes in global structures.

\section{Global Industry 4.0. US, EU, and the New Global Players (Japan, South Korea, China)}

Globalisation has radically modified the traditional fundamental principles of industrial output constituted by: the static localisation of manufacturing facilities; the presence of workers at manufacturing sites; stocks of raw, semi-finished materials, and finished goods stored close to manufacturing facilities and consumer markets; 'long' organisational structures with the rigid, planned, and often fragmented division of roles.

The transformation from MNCs to global networks has led towards vertical specialization and highly diversified patterns of collaboration across inter-firm and intra-firm transactions coordinated by global corporations.

Global networks have significantly reduced the importance of 'context specific skills'. The internet worldwide platform pushes knowledge into a standardized format with minimal costs, readily transferrable across national borders and firms, with business collaboration between modules connected by standardized interfaces (Hayashi, 2002).

The traditional rules of oligopolies have completely changed, with links between firms becoming strategic on a very large scale, and industrial rivalry tending to occur among global networks comprising a multiplicity of firms with different knowledge bases, particularly focused on managing innovation and creative imitation (Brondoni, 2013).

The global competitive innovation and imitation landscapes have significantly changed the relative position of many countries. In particular, the United States has changed its worldwide competitive position, previously governing the diffusion of innovations and the 'block' of imitations, but now having lost its historical leadership, seeking a new role in controlling the innovation and imitation processes.

$\square$ US global firms are very prudent in innovating globally, preferring to produce and sell across the globe through parent companies. From a general point of view, US-based global 
production networks are primarily focused on incremental innovation ('creative imitation') and especially the defending property rights of basic 'essential patents' (Brondoni, 2013).

Conversely, Japanese global production networks primarily focus on innovation and breakthrough technologies with competitive policies to not only innovate globally, but also produce or sell across the globe through their own companies.

Similarly, South Korean global corporations are focusing their policies on creative imitation. South Korean chaebols rapidly industrialized by copying the Japanese international model of economic growth, and in the last 10-15 years, shifted from international markets to global competition, investing heavily in $R \& D$ in the pursuit of corporate mass-market production strategies.

Finally, China's industry has evolved from a distant-follower (primarily focused on imitation) to an immediate follower (with a specific development model), with significant investments in $R \& D$ dedicated to creative product imitation and product/process innovation.

Globalisation has rapidly expanded the market potential of corporations headquartered in countries with a high propensity to innovation (e.g., Japanese companies). Globalisation has also promoted the growth of new countries, especially in the Far East (e.g., South Korea, India, Taiwan), with favourable market conditions (first in terms of low labour costs) to develop advanced skills for innovation and creative imitation (Brondoni, 2013).

By reverse, the main European countries (such as the UK, Germany, and Russia) lost their leadership in innovation, although they played a leading role in the development of last century's closed markets.

For companies operating in global markets, the $4^{\text {th }}$ Industrial Revolution means increasing productivity and production flexibility, with higher product quality, more efficient processes, and completely new business models.

$\square$ For the manufacturing industry, the $4^{\text {th }}$ Industrial Revolution is
not an end but a means. The development guidelines - big data,
open data, Internet of Things, machine-to-machine, cloud
computing, analytics - are tools that allow companies to compete
more effectively in their reference markets, provided they develop
appropriate positioning strategies in global markets (Crapelli,
2018).

The $4^{\text {th }}$ Industrial Revolution technologies determine the transition from the traditional factory model to a new intelligent structure (smart factory) characterized by digital production, interconnected processes, and production systems able to make the best use of available resources.

The changes the $4^{\text {th }}$ Industrial Revolution imposes on business models lead to:

- higher production flexibility through creating small lots at large-scale costs; 
- greater competitiveness of the offer by virtue of the greater functionality deriving from the Internet of Things (IoT);

- much more efficient productivity by reducing errors and reducing set-up times (zero defect production) (Brondoni \& Zaninotto 2018).

\section{4.0, Global Competition and the Extinction of Mammoth Companies}

In open markets, which lack the defence of geographical and administrative boundaries, companies adopt very flexible management behaviours that are characterised by the absolute predominance of intangible resources, and that target the exploitation of global economies of scale.

Corporate policies of 'market space management' that adopt intangible resources sharing, usually take place in different structures belonging to the same network, however they can also involve other organizations as a result of alliances and joint ventures.

Nevertheless, a global corporate management can extend the areas of its activity to include the immaterial dimension and thus construct complex intercompany system relationships that determine competitive positions (for purchases, transformations, distribution and sales) with very temporary and unstable borders because they refer to a (potentially very variable) matrix of goods and businesses.

In recent decades, large corporations have been induced to develop business expansion strategies according to a global business vision. This has been achieved by reorganising distinctive competitive capabilities with economies of scale having more distant borders (market-space competition).

On the other hand, the market-space competition conditions define boundaries having a sophisticated competitiveness and an international matrix. Here, space and time themselves contribute to forming and changing the 'competitive context of reference', thus making, among other things, the evaluation of dominance market conditions very difficult (with the usual performance and position indicators).

Numerous large international corporations were not able to measure up to new global business models and, just like the mammoths, have disappeared. A few casestudies (Polaroid, Blockbuster, Pan Am, GM, Kodak, Compaq) are illustrated below. They are emblematic of the end of an era of corporate policies which were not able to deal with the new logics of competition, as at present for the global oversize management.

3.1 POLAROID (1937-2001). Polaroid is best known for its Polaroid instant film and cameras. Polaroid was one of America's early high-tech success stories.

Founded in 1937 by scientist Edwin Land, the company built its initial business during the interwar period, prospered as a defence contractor during World War II, and then found new success as an innovator in the post-war boom years.

In 1948, Land invented a camera that produced finished photographs in minutes. The invention was an immediate success, and over the next two decades, the instant camera became widely used both in the consumer market and in the business market for 
such purposes as driver's licenses, crime reports, and real estate advertising.

By the ' 60 s and early '70s, Polaroid held a monopoly in the instant photography market, and its sales accounted for about $20 \%$ of the overall market for film and $15 \%$ of the U.S. market for cameras. At its peak the company employed 21,000 people.

Polaroid was not unaware of the progress of electronic imaging; on the contrary, by 1989, 42 per cent of Polaroid's research and development funding was being spent on digital imaging. By the late 1990s Polaroid was a top seller of digital cameras.

However, the company was unable to capitalize on this success. As digital cameras flooded the market, Polaroid began losing some of its big customers in the real estate, insurance, and photo identification businesses. In October 2001, Polaroid filed.

Why was Polaroid unable to make the transition to digital photography?

First, Polaroid leaders believed that customers would always want a hard-copy print. Through the 1990s, Polaroid executives continued to believe in the importance of the paper print. When customers abandoned the print, Polaroid was taken by surprise.

Even though it performed thorough market research, Polaroid was unable to foresee that the photo album would be replaced by the digital slide show.

A related mistaken belief was that the Polaroid Corporation would always be able to make money through developments in chemistry, especially photographic chemistry.

Land was sceptical about investing in electronics. When Edwin Land first invented his camera and film, he imagined that instant photography would change people's lives. Land did not realize how right he was. When he wrote those words, the camera was a bulky appliance, and the print was stored in a heavy album. Today the camera and hundreds of images, which are produced instantly, can be carried in one lightweight device. Now that the camera has been joined to the cell phone and other handheld devices, it is truly "a continuous partner of most human beings". Ironically, the fulfilling of Land's vision led to the end of his company (Nagy Smith, 2009).

Despite its early success in capturing a market that had few competitors, Polaroid was unable to anticipate the impact that digital cameras would have on its film business. Falling into the 'success trap' by exploiting only their (historically successful) business activities, Polaroid neglected the need to explore new territory and enhance their long-term viability.

Even though it performed thorough market research, Polaroid was unable to foresee that the photo album would be replaced by the digital slide show.

The original Polaroid Corporation was declared bankrupt in 2001 and its brand and assets were sold off.

3.2 BLOCKBUSTER (1985-2010). Home movie and video game rental services giant, Blockbuster Video, was founded in 1985. At its peak in 2004, Blockbuster employed 84,300 people worldwide and had 9,094 stores. Unable to transition towards a digital model, Blockbuster filed for bankruptcy in 2010 (Todd \& Higgins, 2013).

$\square$ Blockbuster was founded by David Cook, who had previously owned a business that provided computer software services to the 
oil and gas industry in Texas. Cook saw the potential in the videorental business and after opening the first Blockbuster in 1985; he added three more stores the following year. David Cook, a computer programmer, programmed Blockbuster's computers to track inventory and consumer preferences. Thus, Blockbuster thrived off its ability to provide the films that consumers wanted at individual stores (Gandel, 2010).

By 1988, Blockbuster was America's leading video chain, with some 400 stores. By the early 1990s, Blockbuster had launched its 1,000th store and expanded into the overseas market. In the mid-1990s, the digital video disc (DVD) made its debut and in 1997, Netflix, an online DVD rental service, was founded. Around that same time, the e-commerce giant Amazon.com launched a video and DVD store. Blockbuster faced additional competition from the rise of pay-per-view and on-demand movie services, through which viewers could pay for and watch movies instantly in their own homes.

Blockbuster's business model was disrupted by a number of tech developments, as much from new hardware developments as from competition. Blockbuster remained flat-footed when Netflix started sending videos through the mail, cable and phone companies started offering video-on-demand, and Redbox started renting videos for a buck a night through vending machines. Now that video streams through computers and phones, Blockbuster's conventional retail outlets seem hopelessly outdated.

Blockbuster had a presence in more than a dozen countries around the world, all of which operated as different business holdings, and they have all suffered a similar fate as shifting consumer demands and competition from online-only companies like Netflix Inc. (NASDAQ:NFLX), Hulu, Vadu and Redbox eroded their audience.

At its peak in 2004, Blockbuster had 60,000 employees and 9,000 stores worldwide with a market value of $\$ 5$ billion and revenues of $\$ 5.9$ billion. Ten years later, those figures have dropped dramatically, with revenues of only \$120 million coming from its remaining 300 stores in the U.S. In 2004, Blockbuster launched an online DVD rental service to compete with Netflix. (Hopkins, 2006) The venture was not successful. On 2010, Blockbuster files for bankruptcy as it attempts to wipe out \$1 billion in debt. On September 23, 2010, the company filed for bankruptcy protection. By 2014, the last of the company-owned stores had closed.

The Blockbuster's declining revenue can be attributed to five main events: the rapid growth of new global competitors. In particular, the greatest challenge for Blockbuster was the rapid rise of new competitors utilizing alternative distribution methods to meet customer demand. These competitors acquired substantial market shares and eroded the size of Blockbuster's traditional store-based customer market (Gandel, 2010).

3.3 PAN AM (1927-1991). Pan American World Airways, founded in 1927, was the largest international air carrier in the United States. Pan American World Airways is known as a symbol of the aviation. The airline was the largest international carrier in the United States until its demise in 1991.

$\square 1927$ - Former naval aviator Juan T. Trippe, 28, founds Pan American Airways, a 28-employee operation that inaugurated 
history's first scheduled international flight on Oct. 28--a mail run between a dirt runway in Key West, Fla., and Havana, using a wood-and-fabric Fokker trimotor airplane. Within three months Pan Am was flying passengers between Florida and Cuba. Trippe said his goal was to "provide mass air transportation for the average man at fares he can afford to pay" (Associated Press, 1991).

Pan Am built on air travel's aura of glamour and luxury. For long flights in the 1940s, passengers could reserve sleeping couchettes; New York-to-London passengers were served breakfast in bed. The company was known as an industry innovator. Pan Am was responsible for numerous changes and advances in the aircraft manufacturing industry, major advances in seaplane design and in the development of long-range operation over ocean aircraft such as the Martin M-130 and the Boeing 314 seaplanes. Pan Am was the first airline to offer computerised reservation systems and jumbo jets. At its peak the airline also set two around the world records, both using the B747.

$\square$ Pan Am ushered in cross-Pacific air travel in the mid-'30s with its China Clipper and commercial-jet travel with its Boeing 707; the first jet was christened in grand manner by First Lady Mamie Eisenhower. The carrier came to stand for a questing American spirit - and sound business sense. The entrepreneur who built Pan Am, Juan Trippe, was perfect for the role: part swashbuckler, part tyrant, he made the airline his toy and his obsession. Trippe saw the competitive advantages in going global, often negotiating personally with foreign officials for landing rights. His consultant on new routes was aviator Charles A. Lindbergh. The airline was also a point of civic pride in New York, where the unabashedly ugly headquarters building had almost the star status of Chrysler's nearby skyscraper (Newsweek Staff, 1991).

Despite highly successful years throughout the 1970's, the airline eventually had to end. Due to rising fuel costs, as well as an inability to operate domestic routes the airline was starting to run at a loss. The airline began its long descent. Competition had grown as domestic carriers crowded Pan Am's routes, and many foreign airlines used their government subsidies to undercut Pan Am's prices and at least match its service. Airline-industry deregulation in 1978 removed the last protection old-line carriers like Pan Am had enjoyed. Without a strong domestic-route system to support it, Pan Am's losses mounted.

$\square$ Juan Trippe retired in 1968. President Johnson was no friend of Pan Am. He preferred American and Braniff (both based in his home state of Texas). Neither man was successful in getting Pan Am any domestic routes. When President Nixon came to office in 1969 Pan Am expected to have Johnson's decision reversed but Nixon, after noting that Pan Am was not on his donor list, elected to leave Johnson's decision intact. The government that had been 
so good to Pan Am in its formative years was now seemingly intent on holding it back. However, on October 4, 1978, President Carter deregulated the airline industry and Pan Am was finally free to pursue a domestic feed and cease operations on unprofitable routes. They immediately dropped some European routes and began looking at either starting a domestic feed or buying a domestic carrier.

On 1982, Pan Am begins to trim the work force by $22 \%$ and takes other cost-saving steps. However, Pan Am still loses more than $\$ 480$ million for the year and relations between labour and management become strained. On 1983-84, Pan Am loses nearly \$ 273 million. On 1990, Pan Am sold German service to Lufthansa and negotiates a \$400-million sale of other key routes to United Airlines.

The downfall of Pan Am is attributed to be a combination of corporate mismanagement, government indifference to protecting its prime international carrier, and flawed regulatory policy. Yet around the world, Pan Am's planes were still a symbol of America's global reach. A point tragically driven home by the terrorist bombing of Flight 103 over Lockerbie, Scotland, in 1988.

By over-investing in its existing business model and not investing in future innovations, Pan Am filed for bankruptcy in 1991. Pan Am was able to convince a bankruptcy judge that they were close to making a deal regarding continued operations with TWA on the 3rd December. As such, the airline opened for business as usual on $4^{\text {th }}$ of December, however, was shut down within an hour. Around 7,500 employees instantly lost their jobs. The airline went from the gold standard in service and innovation to bankruptcy in only two decades.

3.4 COMPAQ (1982-2002). Compaq was founded in 1982 by Joseph R. ("Rod") Canion, James M. Harris, and William H. Murto, former Texas Instruments senior managers.

The brand name "COMPAQ" was derived from
"Compatibility and Quality" for creating portable computers.
Compaq was one of the largest sellers of PCs in the entire world in
the 1980s and 1990s. In 1983, Compaq sold 53,000 portable PCs
for more than $\$ 111$ million in revenues.

The company produced some of the first IBM PC compatible computers, being the first company to legally reverse engineer the IBM Personal Computer, i.e. on recreate existing technology as perfectly as possible, including any flaws. So doing, Compaq performed a different approach from companies of the clone market (focused exclusively on low prices), concentrating on new features, such as portability and better graphics displays as well as better performances.

Compaq first perfected and then transformed the IBM PC clone market; in effect, personal computers built to the IBM design were known as IBM-compatible and so far, Compaq became known as one of the best producers of IBM compatibles.

In 1991, the worldwide economic recession and the Gulf War shocked Compaq's profits. Therefore, the company dismissed 1,700 employees and aggressively cut prices to defend market share declines. By 1992, the company was profitable again 
and by 1993, Compaq was the biggest seller of portable PCs in America; and finally, in 1995 the company passed IBM to become the biggest seller of PCs worldwide.

Encouraged by the big profits of the 1990s, Compaq began to compete more hardly with IBM, the Hewlett-Packard Company, and Sun Microsystems.

In 1997, Compaq bought Tandem Computers. Tandem brought Compaq a strong background in high-availability systems for mission critical applications. The next year Compaq purchased Digital Equipment Corporation, one of the oldest computer companies. Digital's presence in major companies, plus its large service organization, added an important enterprise presence for Compaq.

Integrating two giant acquisitions in less than two years had proved difficult; competition from other personal computer makers was cutting profit margins. Unfortunately, Compaq switched the company's long-standing retail strategy to a direct-marketing approach in order to withstand growing competitive pressures from Dell and Gateway. The Compaq's institution of direct marketing was a disaster and decimated its retail distributor network.

Compaq ultimately struggled to keep up in the price wars against Dell and in 2001, Compaq began merger talks with Hewlett-Packard, which was acquired in 2002, for US $\$ 25$ billion. The Compaq brand remained in use by HP for lower-end systems until 2013 when it was discontinued.

3.5 GENERAL MOTORS (1908-2009). General Motors was founded in 1908 by William "Billy" Durant. General Motors Company, formerly General Motors Corporation, was the world's largest motor-vehicle manufacturer for a long time of the $20^{\text {th }}$ and early $21^{\text {st }}$ centuries. GM initially only owned the Buick Motor Company, and later acquired many more companies including Cadillac, Oldsmobile, Pontiac, Vauxhall, Chevrolet and Germany's Opel. The company's major products include automobiles, trucks, automotive components, engines, and also financial services.

By 1930s, General Motors surpassed the Ford Motor Company to become the leading American passenger-car manufacture and the world's largest manufacturer of motor vehicles. By 1941 it had become one of the largest industrial corporations in the world.

In 1971, GM pioneered the use of engines that could run on low lead or unleaded petrol. In the 1980s, GM acquired Hummer and Saab. In 1986, it acquired the Hughes Aircraft Company, a company of weapons systems and communications satellites.

In the 1970s and '80s, GM faced a severe competition from Japanese automakers and in 1984, it began a new automotive division, Saturn, focused on highly automated plants to produce subcompact cars to compete with Japanese imports. By the middle of the 1990s, as other American automakers, GM made a big turnaround and returned its original automotive businesses. It sold Electronic Data Systems in 1996, and in 1997, it sold the defence units of Hughes Electronics. By the early 21st century GM had equity shares in many car corporations, including Isuzu, Subaru, Fuji Heavy Industries, Suzuki and Fiat. In December 2008, Pres. George W. Bush announced an emergency financial rescue plan (the Troubled Assets Relief Program-TARP, a \$700 billion fund approved by Congress) to aid the "Big Three" automakers - Chrysler, General Motors, and Ford - to prevent the collapse of the country's struggling auto industry. As its financial troubles mounted, GM filed for Chapter 11 bankruptcy protection in June 2009. Under scrutiny to pay back loans and become a sustainable corporation, GM has been forced to streamline its brands and focus on the lines that 
have the most potential. In 2010 the company discontinued both the Pontiac and Saturn brands and sold Saab. After this downsizing, GM managed only four vehicle divisions: Buick, Cadillac, Chevrolet, and GMC.

- Some important brands associated with General Motors Company have been challenged in terms of sales and have been abandoned altogether.

- Pontiac. Anyone who paid attention on the road in the 1960 s and 1970s took notice of muscle cars - those sleek, high performance vehicles with V8 engines that could be heard from a mile away. A brand of General Motors, Pontiac made vehicles and muscle cars that defined an era with legendary models. Though Pontiac was at one time one of the top selling brands in the United States, its leadership was unable to devise a strategy that would allow the Pontiac brand to continue. In business since 1926, Pontiac was discontinued in April 2009.

- Saturn. General Motors halted production of its Saturn brand in October 2009 after a deal to sell to Penske Automotive Group failed. Saturn, with a vehicle line that included mostly small to mid-size cars, had been around since 1985. General Motors has enjoyed successful brands over the years, but Saturn struggled and was never profitable.

- Oldsmobile. Oldsmobile was founded as the Olds Motor Vehicle Company in 1897. Claiming to be the first company to mass-produce vehicles, Oldsmobile joined GM in 1908. Oldsmobile, the first brand with fully automatic transmissions, became the best-selling car in the United States in 1976. GM ended manufacturing in 2004, citing that "Oldsmobile production has remained unprofitable” (Folger, 2010).

The current company, General Motors Company, was formed in 2009 and purchased most of the assets of the old GM, including the brand "General Motors". In November 2010 GM returned to the stock market with one of the largest IPOs in U.S. history. The following year GM regained its title as the largest automaker in the world.

After being one of the most important car manufacturers for more than 100 years, and one of the largest companies in the world, General Motors also resulted in one of history's largest bankruptcies.

Failure to innovate and blatantly ignoring competition were key to the company's demise. As GM focused predominantly on profiting from finance, the business neglected to improve the quality of its product, failed to adapt GM to changes in customer needs and did not invest in new technologies.

3.6 KODAK (1889-2012). Eastman's real journey with photography first began in 1877, when he purchased his first camera to take pictures on a trip, he didn't end up making. At the time, photography was an expensive and labour-intensive hobby that required patience and a lot of equipment (Rowbotham, 2014). 
$\square$ George Eastman was born on July 12, 1854, in Waterville, New York. He founded the Eastman Kodak Company in 1892 and started to develop and sell film and cameras for the mass market. In April 1880, George Eastman (Eastman), a junior clerk at Rochester Savings Bank, started manufacturing photographic dry plates on the third floor of a building on State Street in Rochester, US (Collins, 1990).

The commercial production of the dry plates impressed a manufacturer of buggy-whips and family friend Henry Alvah Strong (Strong). Strong provided funding support and later, in 1881, Eastman and he formed a partnership under the name Eastman Dry Plate Company. In the same year, Eastman resigned from his junior clerk post to go full time into his business. In 1884, the partnership was renamed as The Eastman Dry Plate and Film Company. Strong and Eastman became president and treasurer of the company respectively. In 1888, Eastman revolutionized photography with the launch of the 'Kodak' camera. Eastman trademarked the 'Kodak' brand name and the word Kodak was incorporated into the company name. In 1889, the Eastman Photographic Materials Company Limited was incorporated in London, England, to handle the distribution of Kodak products in countries outside the US. In 1892, the company was reorganized and renamed as the Eastman Kodak Company (Hess, 2014).

Eastman Kodak Co, was one of the biggest corporations of the digital age, having failed to quickly embrace modern technologies such as digital photography, its own invention. Eastman Kodak has been a leader in developing new technology in photographic film. It created new, innovative cameras and film technology during the 1960s and 1970s. The peak of the company's success came in the 1970s, when it controlled more than ninety percent of the market share for photographic film.

$\square$ George Eastman chosen the name "Kodak" for the company he founded because the letter " $K$ " had been a favourite of Eastman's, he is quoted as saying, "it seems a strong, incisive sort of letter." He and his mother devised the name Kodak with an anagram set. He said that there were three principal concepts he used in creating the name: it should be short, one cannot mispronounce it, and it could not resemble anything or be associated with anything but Kodak (Zhang, 2011).

In 2012 Eastman Kodak, after 131 years of activity, announced its defeat in front of a digital photography boom in sales. In addition to its consumer businesses segment, Kodak had a commercial segment that included enterprise services, graphics, entertainment and commercial films units. The company's consumer services will also include retail-based photo kiosks (more than 100,000 around the world) and dry lab systems. 
Kodak had already struggled with a crisis once. In 2001 it had to face a lack of liquidity, a complete inability to sell its patents and, finally, a new digital technology.

For example, Kodak invested billions of dollars into developing technology for taking pictures using mobile phones and other digital devices. However, it held back from developing digital cameras for the mass market for fear of eradicating its allimportant film business. Competitors, such as the Japanese firm Canon, grasped this opportunity and have consequently outlived the giant. Kodak's management in the '80s and '90s was unwilling to consider digital as a replacement for film.

Kodak filed for bankruptcy in 2012 and after exiting most of its product streams, re-emerged in 2013 as a much smaller, consolidated company focused on serving commercial customers (Goh, 2018). Kodak had not disclosed its employee numbers since the end of 2010 when it announced that it had a work force of 18,800 employees.

At one time the world's biggest film company, Kodak could not keep up with the digital revolution, for fear of cannibalising its strongest product lines. The leader of design, production and marketing of photographic equipment had a number of opportunities to steer the company in the right direction but its hesitation to fully embrace the transition to digital led to its demise.

Kodak management's inability to see digital photography as a disruptive technology, even as its researchers extended the boundaries of the technology, would continue for decades. As late as 2007, a Kodak marketing video said that Kodak "wasn’t going to play grab ass anymore" with digital.

\section{4.0 IR, Oversize Management and Competitive Globalisation}

Since the beginning of the ' 80 s, the biggest Corporations showed a specific and motivated increasing interest for the economic effectiveness of automation in manufacturing systems. This interest was firstly due to the growing turbulence of the environment, characterised by the markets globalisation, the shortening of product life cycles, the demand for products with better quality and lower prices (over-supply economy).

The business model based on excess supply (i.e., over-supply model, in which rivals face volatile production and progressively falling prices) is now inadequate for aggressive global corporate policies. Producing more and wasting less require today a new global business model based on the progressive disappearance of marginal global companies (oversize economy, characterized by lower production and sales costs, and by large company size) (Brondoni \& Bosetti, 2018).

In oversize economy, the automation in manufacturing systems, of course, is extremely important, and it focuses on the new features of automation technologies; in particular, the diffusion of microelectronics in product and process design (Computer Aided Design, Computer Aided Process Planning, Computer Aided Manufacturing), in manufacturing (robots, Flexible Manufacturing Systems), and in manufacturing management (automated warehouses). 


\begin{abstract}
These new technologies are characterised by a different trade-off between efficiency and flexibility with respect to traditional automated technologies; they enable better quality of conformance; they reduce production costs, with better quality; and finally they reduce the time needed to monitor and respond to environmental changes.
\end{abstract}

Competitive globalisation and oversize economy more and more produce the crisis of standardized productions that has driven companies towards new 4.0 technologies i.e., in the pursuit of new conditions of efficiency that are more open to innovation, towards productive flexibility, and even towards competitive imitation.

Competitive policies must now establish new equilibriums between the reduction of production and sales costs, and the enhancement of non-price competitive factors.

This new corporate growth model finds important key variables in technological innovations, and its management, which is particularly true for microelectronics and information technologies.

Continuous business environmental changes require continuous business adaptations.

Compared to local organization, global competitiveness demands two actions:

- pursuing economies of rapidity when engaging with new resources and markets;

- limiting irreversibility instead of integration, thanks to the possibility of substituting co-makers and partners (suppliers, subcontractors, outsourcers, etc.), or by eliminating a set of external relations and bearing reduced sunk costs.

Ultimately, high transformation costs develop business systems in space-time structures of economies of flexibility. The advantages of "business systems" are clear and significant:

- strategic response times of change, during turbulent system conditions, tend to be favoured by decentralized structures thanks to the presence of adaptive mechanisms which limit delays due to discontinuity phenomena;

- outsourcing system transactions produce 'soft corporation' effects; they transfer growth development and distribution into a fragmented set of decentralized units. The complexity of management problems is associated to certain factors belonging to a competitive framework which include market globalization, the pursuit of collaboration agreements with competitors, product innovation, consumer orientation, as well as information technologies and telematics incorporated into the products.

A further element of complexity can be found in the relationships generated in a competitive environment, since competition leaves increasingly more space for cooperative solutions and the formation of strategic alliances (Brondoni, 2019).

With the creation of intensive knowledge-transfer relationships, the objectives aim at increasing core competencies and changing the conditions of competition. Nonetheless, distinctive skills are based on elements that are not easily transferable, such as acquired knowledge, consolidated operational methods, learning and memory logistics, and longstanding relationships within groups of companies. 


\section{Bibliography}

Agyemang, G., \& Broadbent, J., (2015). Management Control Systems and Research Management in Universities. Accounting, Auditing and Accountability Journal, 28(7), 1018-1046.

http://dx.doi.org/10.1108/AAAJ-11-2013-1531

Ali, M., Babai, M. Z., Boylan, J. E., \& Syntetos, A. A. (2017). Supply Chain Forecasting when Information Is Not Shared. European Journal of Operational Research, 260(3), 984-994.

http://dx.doi.org/10.1016/j.ejor.2016.11.046

Associated Press (1991). The Pan Am Chronology, Los Angeles Times. January 9.

Baur, C., \& Wee, D. (2015). Manufacturing's Next Act. McKinsey \& Company, June.

Beech, N., MacIntosh, R., Krust, P., Kannan, S., \& Dadich, A. (2018). Isuzu: The Solution to Harmonious Engagement between Engineering and Sales, in Managing Change: Enquiry and Action, pp. 291-295. Cambridge: Cambridge University Press.

http://dx.doi.org/10.1017/9781316995624.021

Beech, N., MacIntosh, R., Krust, P., Kannan, S., \& Dadich, A. (2017). A Lawyer's Story: Responding to Change Through Innovation, in Managing Change: Enquiry and Action, pp. 363-366. Cambridge: Cambridge University Press.

http://dx.doi.org/10.1017/9781316995624.032

Beech, N., MacIntosh, R., Krust, P., Kannan, S., \& Dadich, A. (2017). Nokia, in Managing Change: Enquiry and Action, pp. 308-315. Cambridge: Cambridge University Press.

http://dx.doi.org/10.1017/9781316995624.024

Boccardelli, P., Börjesson, S., \& Magnusson, M., (2009). Managing the Efficiency-Flexibility Tension in Innovation: Strategic and Organizational Aspects. Creativity and Innovation Management, 18(1), 2-7.

http://dx.doi.org//10.1111/j.1467-8691.2009.00506.x

Broad, M. J., Senik, R., \& Goddard, A. R. (2008). Perceived Factors Influencing Information Technology (IT) Skills Development in Undergraduate Accounting Programme. International Journal of Economics \& Management, 2(2), 307-322.

http://eprints.soton.ac.uk/id/eprint/167293

Brondoni, S.M. (2019). Shareowners, Stakeholders \& the Global Oversize Economy. The CocaCola Company Case. Symphonya. Emerging Issues in Management (symphonya.unicusano.it), 1, 16-27. http://dx.doi.org/10.4468/2019.1.02brondoni

Brondoni, S. M. (2018). Competitive Business Management and Global Competition. An Introduction, in Brondoni, S. M. (ed.), Competitive Business Management. A Global Perspective. New York \& Turin: Routledge \& Giappichelli.

Brondoni, S. M. (2018). Planned Obsolescence, Total Quality, Zero Defects and Global Competition. Symphonya. Emerging Issues in Management (symphonya.unimib.it), (2), 8-20.

http://dx.doi.org/10.4468/2018.2.02brondoni

Brondoni, S. M., \& Bosetti, L. (2018). Ouverture de 'Integrated CSR Management'. Symphonya. Emerging Issues in Management (symphonya.unimib.it), (1), 1-17.

http://dx.doi.org/10.4468/2018.1.01ouverture

Brondoni, S. M, \& Zaninotto, E. (2018). Ouverture de 'The $4^{\text {th }}$ Industrial Revolution. Business Model Innovation \& Global Competition'. Symphonya. Emerging Issues in Management (symphonya.unimib.it), (2), 1-7.

http://dx.doi.org/10.4468/2018.2.01ouverture

Brondoni, S. M. (2014). Global Capitalism and Sustainable Growth. From Global Products to Network Globalisation, Symphonya. Emerging Issues in Management (symphonya.unimib.it), (1), 10-31.

http://dx.doi.org/10.4468/2014.1.02brondoni

Brondoni, S. M. (2013). Innovation and Imitation for Global Competitive Strategies. The Corporation Development Models of US, Japan, Korea, and Taiwan. Symphonya. Emerging Issues in Management (symphonya.unimib.it), (1), 12-27. 
http://dx.doi.org/10.4468/2013.1.02brondoni

Brondoni, S. M. (2008). Ouverture de 'Market-Driven Management and Global Markets - 2'. Symphonya. Emerging Issues in Management (symphonya.unimib.it), (2), 1-12.

http://dx.doi.org/10.4468/2008.2.01ouverture

Civera, C., \& Freeman, R.E. (2019). Stakeholder Relationships and Responsibilities: A New Perspective. Symphonya. Emerging Issues in Management (symphonya.unicusano.it), (1), 40-58. http://dx.doi.org/10.4468/2019.1.04civera.freeman

Clarke, J. (1997). Shareholders and Corporate Community Involvement in Britain. Business Ethics: A European Review, 6(4), 201-207.

http://dx.doi.org/10.1111/1467-8608.00070

Clarkson, M. B. E. (1995). A Stakeholder Framework for Analysing and Evaluating Corporate Social Performance. The Academy of Management Review, 20(1), 92-117.

http://dx.doi.org/10.3138/9781442673496-013

Collins, D. (1990). The Story of Kodak. New York: Abrams Inc.

Crapelli, R. (2018). Digitalization in Manufacturing Processes, Workshop: IMA Digital and the Adoption of Industry 4.0 Logics, Ozzano. September, 24, 2018.

Folger J. (2010). 5 Dead Auto Brands and Why They Died, Investopedia.

https://www.investopedia.com/financial-edge/0610/5-dead-auto-brands-and-why-they-died.aspx

Freeman, R. E., \& Dmytriyev, S. (2017). Corporate Social Responsibility and Stakeholder Theory: Learning From Each Other. Symphonya. Emerging Issues in Management (symphonya.unimib.it), (2), 7-15.

http://dx.doi.org/10.4468/2017.1.02freeman.dmytriyev

Freeman, R. E. (1984). Strategic Management: A Stakeholder Approach. Boston: Pitman.

Friedman, M. (1970). The Social Responsibility of Firms is to Increase its Profits. New York Times Magazine.

Gandel, S. (2010). How Blockbuster Failed at Failing, TIME, October. 17. http://www.time.com/time/magazine/article/0,9171,2022624,00.html

Goh, F. (2018). 10 Companies that Failed to Innovate, Resulting in Business Failure, in Enterprise Innovation.

https://www.collectivecampus.io/blog/10-companies-that-were-too-slow-to-respond-to-change

Hayashi, T. (2002). Production Networks of Japanese and American Automobile Industry: Contrasting Evolution and Convergence. East West Center Working Papers, Economics Series, $\mathrm{n}$. 45, May, Honolulu.

Hess, R. (2014). Kodak: Rise and Fall of a Legend. Yonsey University, Seoul.

Hewitt-Dundas, N., \& Roper, S. (2017). Exploring Market Failures in Open Innovation. International Small Business Journal, 36(1), 23-40.

http://dx.doi.org/10.1177/0266242617696347

Hopkins, J. (2006). 'Charismatic' founder keeps Netflix adapting. USA Today, April 24.

http://usatoday30.usatoday.com/money/companies/management/2006-04-23-exec-ceo-

profilenetflix x.htm

Klettner, A., Clarke, T., \& Boersma, M. (2014). The Governance of Corporate Sustainability: Empirical Insights into the Development, Leadership and Implementation of Responsible Business Strategy. Journal of Business Ethics, 122(1), 145-165.

http://dx.doi.org/10.1007/s10551-013-1750-y

Lambin, J. J. (2018). The Sharing Economy. A New Strategy to Compete in the Global Market, in Brondoni, S. M. (ed.), Competitive Business Management. A Global Perspective. New York \& Turin: Routledge \& Giappichelli.

Lambin, J. J. (2014). Rethinking the Market Economy. Symphonya. Emerging Issues in Management (symphonya.unimib.it), (2), 4-15.

http://dx.doi.org/10.4468/2014.2.02lambin 
MacLean, D., \& MacIntosh, R. (2017). The Strategy Cycle: Planning, Paradox and Poetry in the Practice of Strategists, in Siebert, S. (ed.), Management Research: European Perspectives, pp. 103120. London: Routledge.

McGuire, S., \& Islam, N. (2015). Indigenous Technological Capabilities, Emerging Market Firms and the Aerospace Industry. Technology Analysis and Strategic Management, 27(7), 739-758.

http://dx.doi.org/10.1080/09537325.2014.959482

McGuire, Steven (2014). Global Value Chains and State Support in the Aircraft Industry. Business and Politics, 16(4), 615-639.

http://dx.doi.org/10.1515/bap-2014-0014

Mosca, F., Tamborrini, P., \& Casalegno, C. (2015). Systemic Design: How to Compete by Leveraging the Value System. Symphonya. Emerging Issues in Management (symphonya.unimib.it), (2), 42-56. http://dx.doi.org/10.4468/2015.2.04mosca.tamborrini.casalegno

Nagy Smith, A. (2009). What was Polaroid thinking? Yale Insights November 04, Yale School of Management.

Newsweek Staff (1991). Pan American World Airways: 1927-1991. Newsweek, July 21.

Porter, M. E., \& Kramer, M. R. (2011). Creating Shared Value. Harvard Business Review, 89(1/2), 62-77.

Rowbotham, C. (2014). The Early Days of Kodak: The Strategies Eastman Used to Form his Legacy, July 14.

https://library.ryerson.ca/asc/2014/07/the-early-days-of-kodak-the-strategies-eastman-used-to-

form-his-legacy/

Sabet, E., Adams, E., \& Yazdani, B. (2016) Quality Management in Heavy Duty Manufacturing Industry: TQM vs. Six Sigma. Total Quality Management \& Business Excellence, 27(1-2), 215225.

http://dx.doi.org/10.1080/14783363.2014.972626

Salvioni, D. M., \& Gennari, F. (2019). Stakeholder Perspective of Corporate Governance and CSR Committees. Symphonya. Emerging Issues in Management (symphonya.unicusano.it), (1), 28-39.

http://dx.doi.org/10.4468/2019.1.03salvioni.gennari

Salvioni, D. M. (2018). Corporate Governance, Ownership and Global Markets, in Brondoni, S. M. (ed.), Competitive Business Management. A Global Perspective. New York \& Turin: Routledge \& Giappichelli.

Salvioni, D. M. (2016). Hotel Chains and the Sharing Economy in Global Tourism, Symphonya. Emerging Issues in Management (symphonya.unimib.it), (1), 31-44.

http://dx.doi.org/10.4468/2016.1.04salvioni

Salvioni, D. M., Gennari, F., \& Bosetti, L. (2016). Sustainability and Convergence: The Future of Corporate Governance Systems? Sustainability, 8(11): 1203.

http://dx.doi.org/10.3390/su8111203

Salvioni, D. M., \& Bosetti, L. (2014). Stakeholder Engagement and Integrated Reporting: Evidence from the Adoption of the IIRC Framework, Journal of Strategic and International Studies, 9(3), 78 89.

Salvioni, D. M., \& Bosetti, L. (2014). Sustainable Development and Corporate Communication in Global Markets, Symphonya. Emerging Issues in Management (symphonya.unimib.it), (1), 32-51.

http://dx.doi.org/10.4468/2014.1.03salvioni.bosetti

Severo, E. A., de Guimarães, J. C. F., \& Henri Dorion, E. C. (2018). Cleaner Production, Social Responsibility and Eco-Innovation: Generations' Perception for a Sustainable Future. Journal of Cleaner Production, 186, 91-103.

http://dx.doi.org/10.1016/j.jclepro.2018.03.129

Sigurdson, J. (1990). The Internationalization of $R \& D$ - An Interpretation of Forces and Responses, in Sigurdson, J. (ed.), Measuring the Dynamics of Technological Change, London: Pinter.

Suchman, M. C. (1995). Managing Legitimacy: Strategic and Institutional Approaches. The Academy of Management Journal, 20(3), 571-610. 
(C) SYMPHONYA Emerging Issues in Management, 2, 2019

symphonya.unicusano.it

http://dx.doi.org/10.5465/AMR.1995.9508080331

Todd, D. \& Higgins, J. (2013). A Blockbuster Failure: How an Outdated Business Model Destroyed a Giant, Chapter 11 Bankruptcy Case Studies.

http://trace.tennessee.edu/utk_studlawbankruptcy/11

Zhang, M. (2011). Origin and Evolution of Kodak's Name and Logo, August 3.

https://petapixel.com/2011/08/03/origin-and-evolution-of-kodaks-name-and-logo/\#disqus_thread 